\title{
PENINGKATAN CITA RASA BUMBU WOKU PADA IKAN TUNA
}

\author{
IMPROVED TASTE "woku" HERBS IN "TUNA" \\ Fetty Indriaty dan Hilda F. G Kaseke \\ Balai Riset dan Standardisasi Industri Manado \\ Jalan Diponegoro No: 21-22 Manado \\ Pos-el: indriatyfetty@yahoo.com \\ Diterima tgl 22-07-2016, Disetujui tgl 20-08-2016
}

\begin{abstract}
ABSTRAK
Woku adalah bumbu makanan khas Sulawesi Utara yang terbuat dari berbagai macam bumbu, biasa digunakan untuk memasak atau membumbui daging dan ikan. Penelitian peningkatan cita rasa bumbu woku pada ikan tuna telah dilaksanakan. Tujuan penelitian yaitu mengetahui formulasi bumbu inti woku yang diaplikasikan pada ikan tuna.Penelitian ini menggunakan metode deskriptif.Data yang diperoleh dianalisis secara diskriptif dan ditampilkan dalam bentuk tabel, histogram, yang menjadi perlakuan yaitu penambahan bumbu inti 10, 15, 20, 25 dan 30\%. Pengamatan dilakukan terhadap penampakan, warna, rasa, kadar air, protein, lemak, abu, Angka Lempeng Total (ALT), kapang. Formulasi bumbu inti dengan cita rasa woku dapat diaplikasikan pada ikan tuna. Hasil penelitian yang terbaik yang dapat direkomendasikan yaitu pada perlakuan penambahan bumbu inti rasa woku 30\% (E) diperoleh kadar air 66,96\%, protein 22,30\%, lemak 3,73\%, kadar abu 2,12\%, angka lempeng total (ALT) $1,5 \times 10^{3}$ koloni/g, kapang <10 koloni/g dengan penampakan 4,13 (suka), rasa 4,5 (suka), dan warna 4,16 (suka).
\end{abstract}

Kata Kunci: ikan, bumbu "woku"

\section{ABSTRACT}

Woku is a type of bumbu (spice mixture) found in Manado cuisine of North Sulawesi, made from a variety of spices usually used for cooking or seasoning meat and fish menus. Research about how to improve taste woku seasoning on tuna have been implemented. The research objective is to know the best formulations applied on tuna. This research uses descriptive method. Data were analyzed descriptively and presented in tabular form, histogram. The treatment carried by the addition of basic seasoning 10, 15, 20, 25 and 30\% tuna weight. Observations were made to the appearance, color, taste, moisture content, protein, fat, ash, Total Plate Count (TPC), and molds. Results of the study recommended the additional basic woku seasoning $30 \%$ (E) which obtained moisture content $66.96 \%, 22.33 \%$ protein, $3.73 \%$ fat, $2.12 \%$ ash content, total plate count (TPC) 1,5x105 colonies/g with 4.13 apperance (like), taste 4.5 (like), and the color of 4.16 (like).

Keywords: Fish, Woku Seasoning.

\section{PENDAHULUAN}

Penganekaragaman produk olahan perikanan merupakan salah satu usaha untuk meningkatkan produksi. Apalagi akhir-akhir ini produk olahan ikan sebagai bahan makanan sudah beredar di pasaran, baik secara tradisional maupun dengan cara modern. Hasil perikanan laut yang melimpah telah dimanfaatkan oleh industri yang ada, baik industri menengah, industri kecil, maupun industri rumah tangga.
Ikan merupakan salah satu hasil perairan yang banyak dimanfaatkan oleh manusia karena beberapa kelebihannya, antara lain merupakan sumber protein hewani yang sangat potensial karena pada daging ikan dapat dijumpai senyawa yang sangat penting bagi manusia yaitu karbohidrat, lemak, protein, garam-garam mineral dan vitamin. Kandungan zat gizi tersebut menyebabkan ikan sangat digemari sehingga kebutuhan konsumsi ikan semakin meningkat.Ikan sebagai 
sumber alami asam lemak omega 3 yaitu Eicosapentaenoic Acid(EPA) dan Decosahexaenoic Acid (DHA) yang berfungsi mencegah aterosklerosis terutama EPA. Keduanya dapat menurunkan secara nyata kadar trigliserida di dalam darah dan menurunkan kadar kolesterol hati dan jantung. Kadar asam lemak omega 3 dalam beberapa jenis ikan laut di perairan Indonesia berkisar antara 0,1-0,5 g/100g daging ikan seperti ikan sidat, terumbuk, tenggiri, kembung, layang, bawal, srengseng, tuna, dan sebagainya. Ikan tuna ialah jenis ikan dengan kandungan protein yang tinggi dan lemak yang rendah. Ikan tuna mengandung protein antara 22,6-22,2 g/100 g daging, lemak antara 0,2-2,7 $\mathrm{g} / 100 \mathrm{~g}$ daging. Disamping itu ikan tuna mengandung mineral, kalsium, fosfor, besi, sodium, vitamin A (retinol) dan vitamin B (thiamin, riboflavin, niasin)(1).

Beberapa produk industri pengalengan ikan di Sulawesi Utara terdapat berbagai cita rasa, namun ada produk olahan ikan kaleng dengan cita rasa lokal seperti woku yang belum sesuai dengan cita rasa konsumen pada umumnya, sehingga perlu dilakukan penelitian formulasi bumbu woku, untuk produk tuna kaleng cita rasa woku.

$$
\text { Bumbu adalah proses }
$$

menyampaikan rasa atau meningkatkan rasa dari makanan. Bumbu adalah tanaman aromatik yang ditambahkan pada makanan sebagai penyedap dan pembangkit selera makan diantaranya, cabai, jahe, bawang, daun salam, kunyit, sereh dan sebagainya. Rempah-rempah merupakan tanaman aromatik yang dibutuhkan pada makanan sebagai penyedap dan pembangkit selera. Pada umumnya jenis tumbuhan tersebut mengandung substansi yang sangat membantu kelenjar-kelenjar pencernaan dan meningkatkan rangsangan nafsu makan. Contoh rempah-rempah antara lain lada, kapulaga, cengkeh, kemiri dan sebagainya. Secara fungsional, bumbu dan rempah artinya sama karena sama-sama memberikan rasa dan aroma yang khas pada makanan. Fungsi bumbu ialah untuk memperkaya rasa masakan misal rasa harum, manis, asam gurih, asam atau pedas. Bumbu woku ataupun rempahrempah yang digunakan dalam masakan Minahasa memegang peranan penting, dengan kata lain masakan Minahasa banyak menggunakan rempah-rempah dalam pembuatannya (2). Beberapa bumbu dapur yang digunakan untuk memasak woku yaitu kemangi, daun jeruk, daun pandan, kunyit, serai, daun bawang, tomat, cabai, jahe, bawang putih, bawang merah dan kemiri.

Baristand industri Manado telah melakukan penelitian bumbu intimasak Minahasa dalam bentuk serbuk kering dan pasta sampai dengan penyimpanan 4 bulan masih dapat diterima oleh panelis (3).Tujuan penelitian yaitu mengetahui formulasi bumbu inti woku yang diaplikasikan pada ikan tuna.

\section{BAHAN DAN METODE}

\section{Bahan dan Alat}

Bahan-bahan yang digunakan dalam penelitian ini yaitu bahan baku ikan tuna yang diperoleh dari pedagang di Pasar Bersehati, Manado. Bumbu yang digunakan 
yaitu cabai, jahe, serai, kunyit, kemiri, bawang merah, bawang putih, kemangi, daun jeruk, daun pandan, daun kunyit, dan bahan-bahan untuk analisis mutu.

Alat-alat yang digunakan dalam penelitian ini yaitu grinder, kompor, wajan, kukusan, panci stainless, pisau, talenan, pengaduk, cool box, timbangan, kemasan, dan peralatan untuk analisis mutu.

\section{Metode penelitian}

Penelitian ini menggunakan metode deskriptiftiga kali ulangan yang menjadi perlakuan penambahan bumbu inti:

A: Bumbu inti 10\% dan daging ikan $90 \%$

B: Bumbu inti $15 \%$ dan daging ikan $85 \%$

C:Bumbu inti 20\% dan daging ikan $80 \%$

D: Bumbu inti 25\% dan daging ikan $75 \%$

E: Bumbu inti 30\% dan daging ikan $70 \%$

\section{Prosedur Kerja}

1. Persiapan pembuatan bumbu inti masakan Minahasa (woku).

Pembuatan bumbu inti ini dilakukan dengan mempersiapkan formula yaitu kunyit $12 \%$, bawang putih $8 \%$, bawang merah $18 \%$, cabai $22 \%$, serai $10 \%$, jahe $10 \%$, dan kemiri $20 \%$ (3).

2. Pembuatan bumbu inti.

Rempah-rempah yang sudah dipilih dicuci dengan air bersih, kemudian ditiriskan, dan semua bahan dihaluskan dengan grinder. Setelah dihaluskan ditambahkan garam halus $5 \%$ dari berat bahan, dicampur secara homogen, kemudian dimasak dalam minyak sayur panas sebanyak $20 \%$ dari berat bahan. Setelah selesai dimasak, bumbu dibiarkan pada suhu kamar, didinginkan, dan dilakukan pengemasan.

3. Persiapan ikan tuna.

Ikan tuna dibuang isi perut, kepala, ekor dan daging yang berwarna hitam. Difillet untuk memisahkan antara kulit, daging dan tulang. Daging ikan tuna yang sudah difillet dicuci bersih kemudian dipotongpotong sebesar $3 \times 3 \mathrm{~cm}$ kemudian diberikan perasan lemon cui (Citrus mitis) sebanyak $3 \%$ dari berat ikan. Dicampur sampai rata, biarkan selama 15 menit.Selanjutnya dilakukan pengukusan selama45 menit.

4. Pencampuran bumbu dan ikan. Ikan yang sudah dikukus didinginkan kemudian ditimbang sesuai dengan perlakuan.Bumbu inti woku yang telah disiapkan, ditimbang sesuai perlakuan, dan ditumis.Ikan yang sudah dikukus dimasukkan ke dalam tumisan bumbu inti woku, dicampur hingga homogen.Pemasakan dilakukan kurang lebih 15-20 menit.Selanjutnya produk tuna woku dimasukkan kedalam kemasan gelas jar yang sudah disterilkan.

\section{Pengamatan}

Pengamatan dilakukan terhadap kadar air (metode oven, SNI 01-2891-1992) (4), protein (SNI 01-2891-1992) (4), lemak (SNI 01-2891-1992) (4), kadar abu (SNI 012891-1992)(4), cemaran mikroba (Angka Lempeng Total) (SNI 19-2897-1992) (5),Escherichia coli(SNI 19-2897-1992) 
(5),uji organoleptik meliputi rasa, aroma, diikuti oleh 20 panelis terlatih dan tidak terlatih dengan dengan memberi skor nilai: 5 (sangat suka), 4 (suka), 3 (agak suka), 2 (tidak suka), 1 (sangat tidak suka).

HASIL DAN PEMBAHASAN

Kadar Air tuna woku dapat dilihat pada Gambar 1.

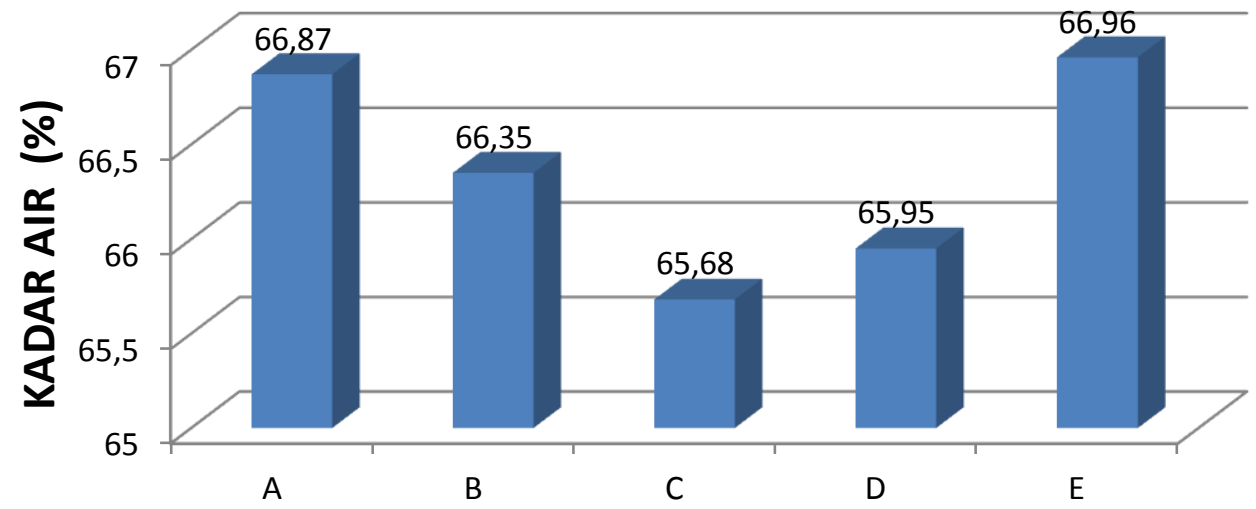

IKAN TUNA WOKU

Gambar 1. Hasil Analisis Kadar Air Ikan Tuna Woku

Keterangan :A: Bumbu inti 10\% dan daging ikan 90\%; B: Bumbu inti 15\% dan daging ikan $85 \%$; C: Bumbu inti $20 \%$ dan daging ikan $80 \%$; D: Bumbu inti $25 \%$ dan daging ikan $75 \%$; E: Bumbu inti $30 \%$ dan daging ikan $70 \%$

Rata-rata kadar air dari ikan tuna woku berkisar antara 65,68-66,96\%. Kadar air tertinggi diperoleh pada perlakuan penambahan bumbu woku $30 \%$ (E) yaitu sebesar $66,96 \%$, kadar air ikan tuna woku terendah diperoleh pada perlakuan penambahan bumbu woku $20 \%$ (C) yaitu sebesar $65,68 \%$. Perbedaan kandungan air dalam ikan tuna woku karena perlakuan penambahan bumbu woku dengan persentase yang berbeda.

Kadar air dari ikan tuna woku yang dihasilkan dipengaruhi oleh proses pengolahan, suhu, waktu pemasakan, volume bahan yang digunakan serta berasal dari bahan baku itu sendiri. Kisaran kadar air ikan tuna woku yang diperoleh masih lebih rendah dari SNI (1995) yang menyatakan syarat maksimum kadar air bakso ikan sebesar 80\%, sedangkan produk kamaboko dengan perlakuan konsentrasi berbeda tepung ubi jalar dan sagukadar air berkisar antara 67,39$70,31 \%(6)$. 
Kandungan air dalam bahan makanan ikut memberikan acceptability, kesegaran, dan daya tahan bahan. Air juga merupakan komponen penting dalam bahan makanan karena air dapat mempengaruhi penampakan, tekstur, serta cita rasa makanan (7).

Protein
Hasil analisis kadar protein ikan tuna woku yang ditunjukkan pada Gambar 2 berkisar antara $19,5-22,36 \%$. Kadar protein tertinggi sebesar 22,36\% diperoleh pada perlakuan penambahan bumbu woku $25 \%$ (D) dan kadar protein terendah sebesar 19,5\% diperoleh pada perlakuan penambahan bumbu woku $10 \%(A)$.

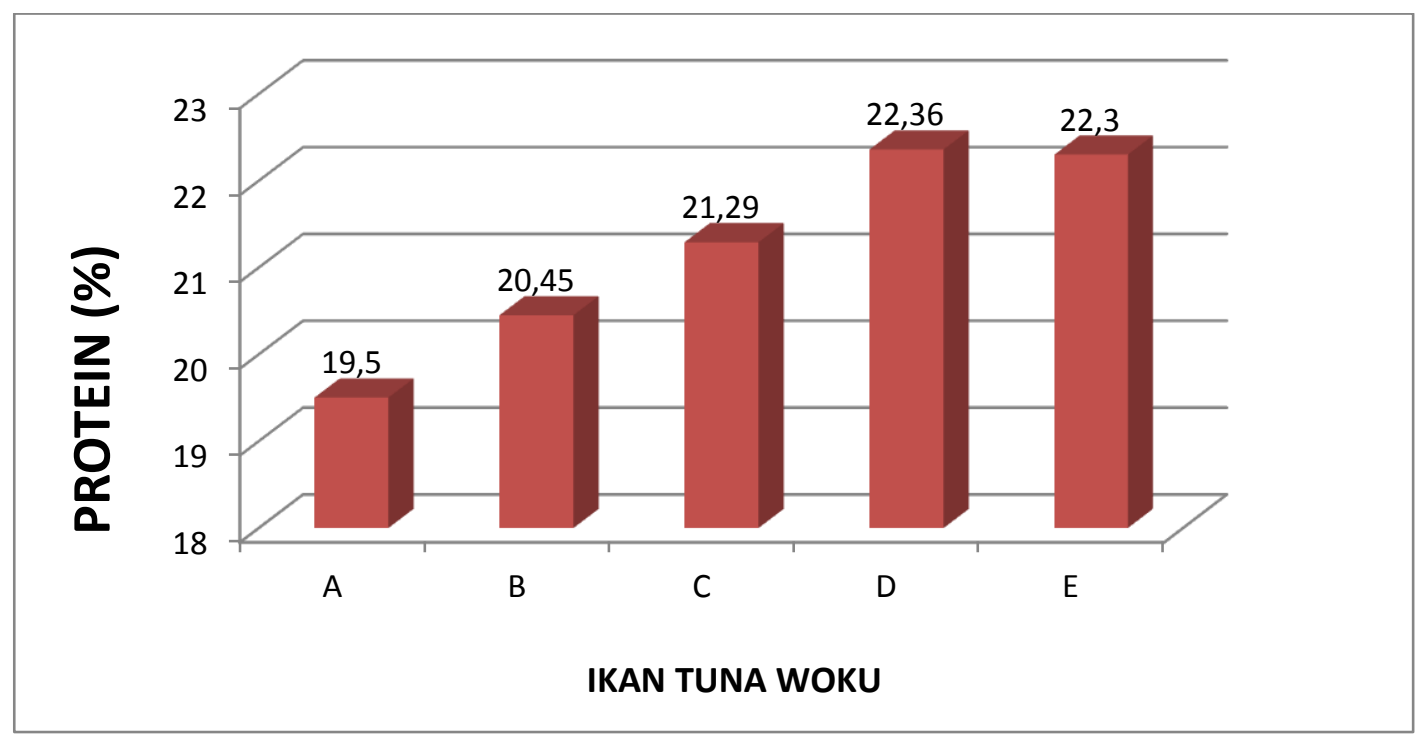

Gambar 2. Hasil Analisis Protein Ikan Tuna Woku

Keterangan :A: Bumbu inti 10\% dan daging ikan 90\%; B: Bumbu inti 15\% dan daging ikan 85\%; C: Bumbu inti $20 \%$ dan daging ikan $80 \%$; D: Bumbu inti $25 \%$ dan daging ikan $75 \%$; E: Bumbu inti $30 \%$ dan daging ikan $70 \%$

Protein merupakan suatu zat makanan yang sangat penting bagi tubuh manusia karena berfungsi sebagai sumber energi,bahan pengatur dan bahan pembangun(7).Protein adalah sumbersumber asam amino yang mengandung unsur karbon, hidrogen, oksigen dan nitrogen. Sumber nitrogen ini tidak dimiliki lemak dan karbohidrat (8). Protein berperan dalam memelihara keseimbangan air dan elektrolit dan asam basa.Protein juga berperan dalam pembentukan senyawa esensial seperti hormon, enzim, hemoglobin, rhodopsin, precursor, vitamin (niasin dari triptrofan), serotonin sebagai neurotransmitter monoamino dan antibodi (9).

\section{Lemak}

Hasil analisis lemak ikan tuna woku berkisar antara 3,12-3,80\% (Gambar 3). Kadar lemak ikan tuna woku tertinggi sebesar 3,80\% diperoleh pada perlakuan penambahan bumbu inti woku 20\% (C). Kadar lemak ikan tuna woku terendah sebesar 3,12\% diperoleh pada perlakuan penambahan bumbu woku $10 \%(\mathrm{~A})$. 


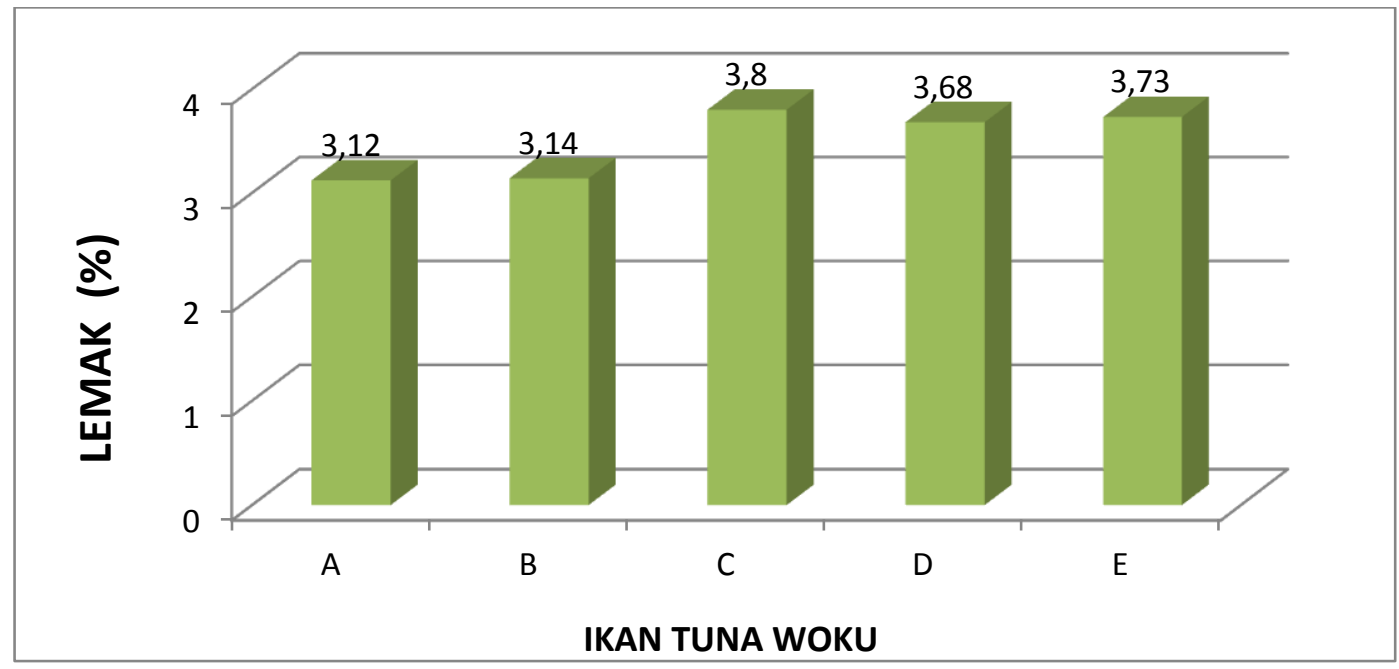

Gambar 3. Hasil Analisis Lemak Ikan Tuna Woku

Keterangan :A: Bumbu inti 10\% dan daging ikan 90\%; B: Bumbu inti 15\% dan daging ikan 85\%; C: Bumbu inti $20 \%$ dan daging ikan $80 \%$; D: Bumbu inti $25 \%$ dan daging ikan $75 \%$; $\mathrm{E}$ : Bumbu inti 30\% dan daging ikan $70 \%$

Lemak merupakan sumber tenaga yang kedua setelah karbohidrat. Molekul lemak terdiri dari unsur karbon, hidrogen dan oksigen. Fungsi dari lemak memberikan kalori, dimana setiap gram lemak memberikan 9 kalori. Lemak juga berfungsi melarutkan vitamin $A, D, E, K$ sehingga dapat diserap oleh dinding usus halus dan memberikan asam-asam lemak esensial. Asam lemak esensial tidak dapat dibuat oleh tubuh, harus diambil dari makanan dan berfungsi untuk melindungi alat-alat tubuh yang halus. Rata-rata manusia membutuhkan 3/4-1 gram perkilogram berat badan. Terdapat 20-25\% dari kebutuhan kalori sehari diperoleh dari lemak(10).

\section{Kadar Abu}

Dari hasil analisis kadar abu ikan tuna woku berkisar antara 1,32-2,15\%
(Gambar 4). Kadar abu ikan tuna woku tertinggi sebesar 2,15\% diperoleh pada perlakuan penambahan bumbu inti 30\% $(E)$, kadar abu ikan tuna woku terendah sebesar $1,32 \%$ pada perlakuan penambahan bumbu inti $10 \%$ (A). Pada gambar 4 menunjukan bahwa semakin tinggi persentase bumbu inti yang ditambahkan semakin banyak kandungan bahan organik didalam produk tersebut.

Kadar abu adalah sisa hasil pembakaran suatu bahan organik (11). Kadar abu berhubungan dengan mineral suatu bahan. Mineral suatu bahan merupakan garam organik (garam-garam malat, asetat, pektat) dan garam anorganik (garam fosfat, karbonat, klorida, sulfat dan nitrat). Makanan yang berasal dari hewani mengandung kadarabu yang tinggi(12). 


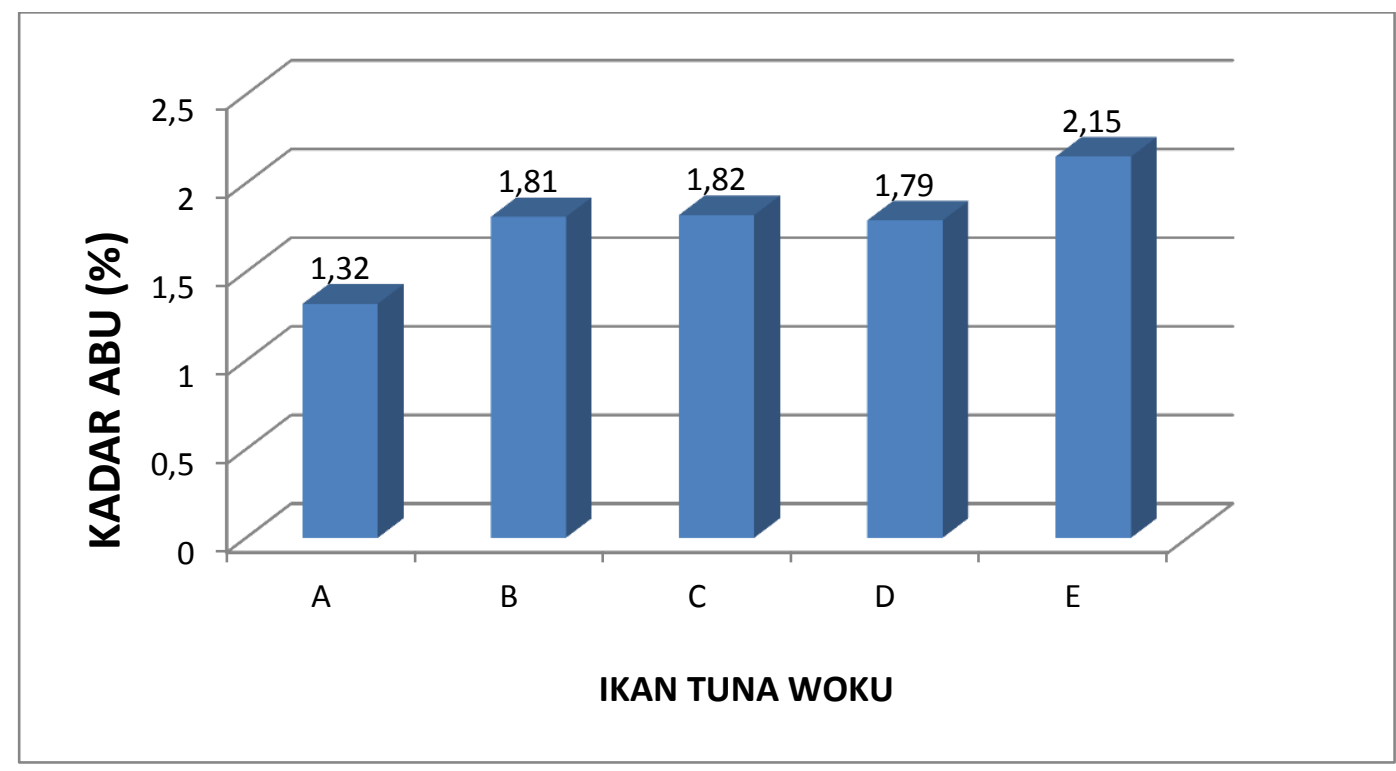

Gambar 4. Hasil Analisis Kadar Abu Ikan Tuna Woku

Keterangan :A: Bumbu inti 10\% dan daging ikan 90\%; B: Bumbu inti 15\% dan daging ikan $85 \%$; C: Bumbu inti $20 \%$ dan daging ikan $80 \%$; D: Bumbu inti $25 \%$ dan daging ikan $75 \%$; E: Bumbu inti 30\% dan daging ikan 70\%

Uji Mikrobiologi (Angka Lempeng Total dan Kapang)

Kontaminasi mikroba pada produk pangan dapat disebabkan oleh berbagai hal, yaitu alat, wadah, ruangan, udara dalam lingkunganpengolahan, dan pekerja itu sendiri, atau kontaminasi silang dari produk jadi yang bercampur dengan bahan baku dan penanganan yang tidak baik setelah pengolahan (13). Oleh karena itu, uji mikrobiologi merupakan salah satu uji yang penting karena dapat digunakan sebagai indikator sanitasi dan indikator keamanan produk pangan.

Hasil analisis terhadap Angka Lempeng Total pada ikan tuna woku memiliki kisaran $1,5 \times 10^{3}-3 \times 10^{3}$ koloni/g. Kisaran nilai ini masih sesuai dengan persyaratan SNI 01-2897-1992 yang mensyaratkan batas maksimal jumlah Angka Lempeng Total ialah $5 \times 10^{3}$ koloni $/ \mathrm{g}$ (5).

Tabel 1. Uji Mikrobiologi (Angka Lempeng Total dan Kapang)

\begin{tabular}{ccc}
\hline $\begin{array}{c}\text { Perlakuan } \\
\text { Bumbu Inti (\%) }\end{array}$ & ALT (Koloni/g) & Kapang (koloni/g) \\
\hline 10 & $3 \times 10^{3}$ & $<10$ \\
15 & $1,5 \times 10^{3}$ & $<10$ \\
20 & $2 \times 10^{3}$ & $<10$ \\
25 & $2 \times 10^{3}$ & $<10$ \\
30 & $1,5 \times 10^{3}$ & $<10$ \\
\hline & pangan penting untuk mengukur tingkat
\end{tabular}

\section{Kapang}

Kapang merupakan salah satu faktor penentu kualitas suatu produk pangan. Analisis total mikro organisme pada bahan kesegaran kualitas sanitasi pangan selama penanganan transportasi dan penyimpanan. Hasil pengujian terhadap total kapang pada ikan tuna woku setelah 
disimpan 2 minggu dengan perlakuan penambahan bumbu inti $10-30 \%$ jumlah koloni kapang $<10$ koloni/g. Pertumbuhan kapang dipengaruhi oleh beberapa faktor, seperti kandungan nutrient, substrat, $\mathrm{pH}$, suhu, tersedianya oksigen.

Pertumbuhan kapang seperti bulu atau rambut disebut mycilia dan pada ujungnya berbentuk seperti buah yang disebut konidia dan mengandung spora kapang yang berwarna hijau, hitam dan putih (14).

\section{Uji Organoleptik}

1) Penampakan

Penampakan adalah kriteria penting karena dapat mempengaruhi penerimaan konsumen terhadap produk, sebab pertama kali menilai panelis mutu produk adalah penampakan secara visual. Hasil organoleptik tingkat kesukaan panelis terhadap penampakan akan tuna woku diperlihatkan pada Gambar 5.

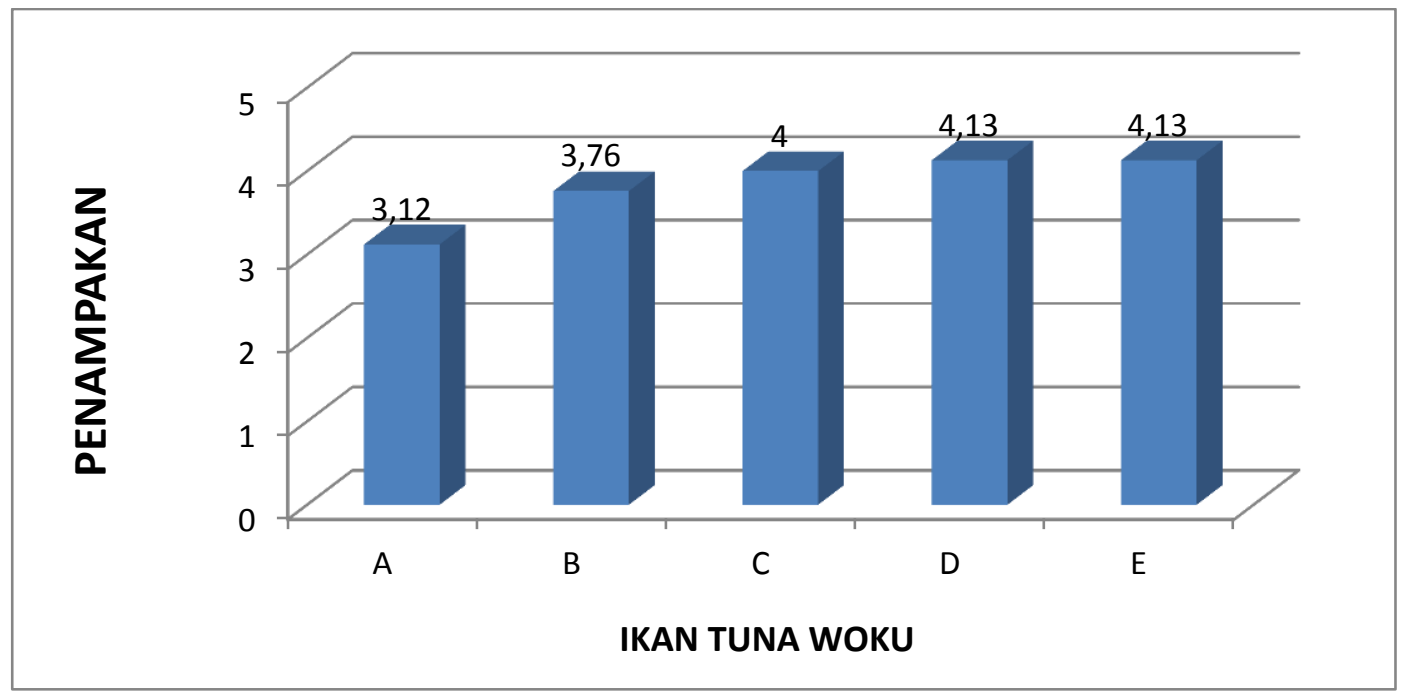

\section{Gambar 5. Uji Organoleptik Ikan Tuna Woku Terhadap Penampakan}

Keterangan :A: Bumbu inti 10\% dan daging ikan 90\%; B: Bumbu inti 15\% dan daging ikan 85\%; C: Bumbu inti 20\% dan daging ikan 80\%; D: Bumbu inti 25\% dan daging ikan $75 \%$; E: Bumbu inti $30 \%$ dan daging ikan $70 \%$

Rata-rata tingkat kesukaan panelis terhadap penampakan pada ikan tuna woku yaitu berkisar antara 3,12-4,13 (agak suka) sampai 4,13 (suka). Panelis secara umum suka terhadap penampakan ikan tuna woku.Terlihat pada Gambar 5 bahwa penambahan bumbu woku yang disukai yaitu adalah $20 \%$, 25\% dan $30 \%$.

Semakin banyak bumbu woku yang ditambahkan, maka tingkat kesukaan panelis terhadap penampakan ikan tuna woku meningkat.Tingkat kesukaan panelis terhadap penampakan ikan tuna woku terkait dengan komponen bumbu yang terkandung didalamnya, berperan dalam memperkaya flavor, aroma, tekstur, dan penampakan dari keseluruhan suatu produk makanan (15).

2) Rasa

Rasa merupakan persepsi dari sel pengecap yang meliputi rasa asin, asam, dan pahit yang diakibatkan 
oleh bahan yang terlarut dalam mulut (16).Hasil organoleptik tingkat kesukaan terhadap rasa ikan tuna

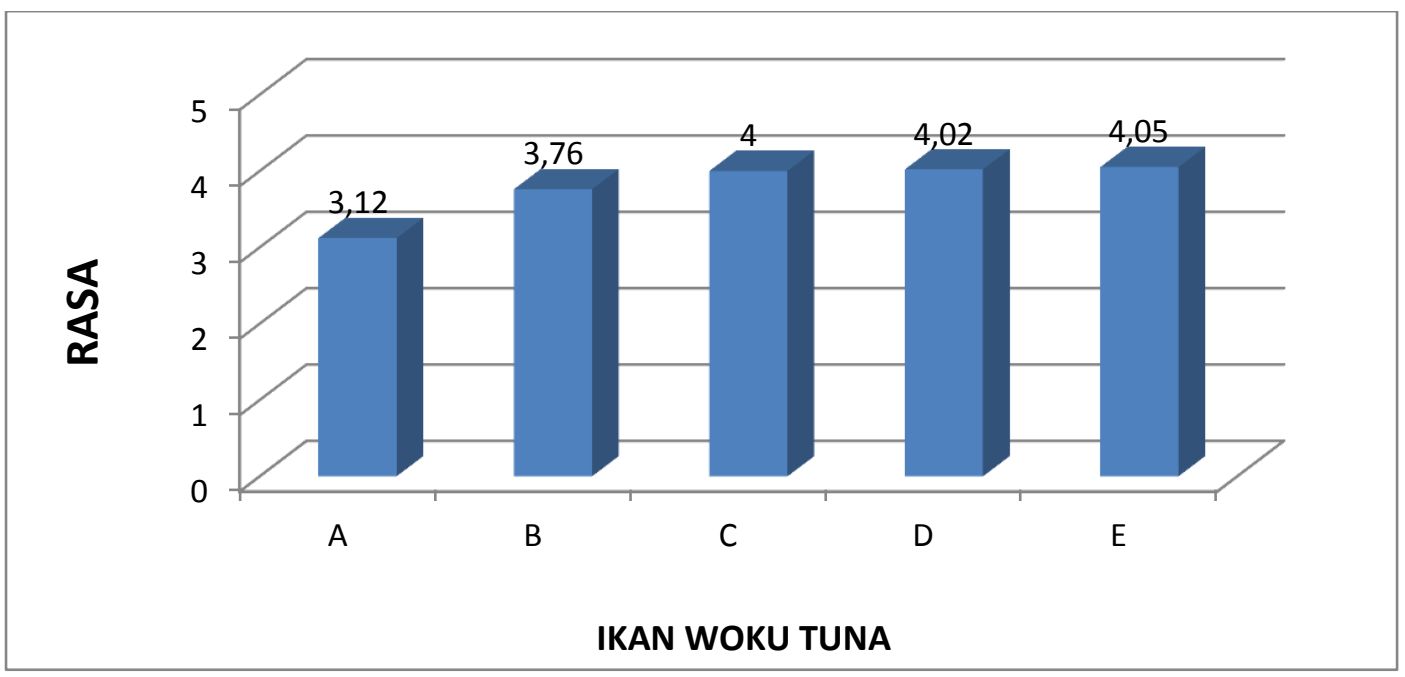

\section{Gambar 6. Uji Organoleptik Ikan Tuna Woku Terhadap Rasa}

Keterangan :A: Bumbu inti 10\% dan daging ikan 90\%; B: Bumbu inti 15\% dan daging ikan $85 \%$; C: Bumbu inti $20 \%$ dan daging ikan $80 \%$; D: Bumbu inti $25 \%$ dan daging ikan $75 \%$; $\mathrm{E}$ : Bumbu inti $30 \%$ dan daging ikan $70 \%$

Penilaian panelis terhadap tingkat kesukaan rasa ikan tuna woku yaitu berkisar 3,12 (agak suka)sampai 4,05 (suka). Perlakuan yang paling disukai panelis pada tingkat kesukaan terhadap rasa ikan tuna woku adalah perlakuan bumbu woku $30 \%$ (E) yaitu rata-rata penilaian 4,05 (suka).

Di dalam bumbu woku salah satu bumbu yang ditambahkan yaitu cabai.Zat yang membuat cabai terasa pedas yakni capcaisin yang bersifat stomatik, yang dapat meningkatkan nafsu, kemampuannya merangsang hormon endorphin yang mampu membangkitkan sensasi kenikmatan. Cabai kaya akan karbohidrat, protein, lemak (vitamin B, C, dan vitamin E), flavonoid, capcaisin, mineral, air dan serat. Cabai mengandung senyawa antioksidan yang dapat melindungi tubuh dari radikal bebas penyebab kanker. Beberapa seyawa antioksidan yang terdapat dalam cabai, yaitu vitamin C, vitamin $\mathrm{E}$, vitamin $\mathrm{K}$, fitosterol, betakaroten dan betacriptoxanthin (17).

Bumbu lain yang digunakan adalah pada penelitian ini adalah kunyit, bawang merah, bawang putih, jahe dan sereh. Kunyit mengandung kurkuminoid, yaitu senyawa yang berkhasiat sebagai obat. Bawang merah dan bawang putih selain berfungsi sebagai penyedap yang membuat masakan menjadi lebih beraroma dan mengundang selera. Jahe memiliki kandungan senyawa aktif yang mampu memberi rasa pedas dan memiliki efek antioksidan (1).

\section{3) Warna}

Warna merupakan komponen yang sangat penting untuk menentukan kualitas atau derajat penerimaan suatu bahan pangan.Suatu bahan pangan meskipun dinilai enak dan 
teksturnya sangat baik, tetapi memiliki warna yang kurang sedap dipandang atau memberikan kesan menyimpang dari warna yang seharusnya, maka tidak layak dikonsumsi.Penentuan mutu suatu bahan pangan pada umumnya tergantung pada warna, karena warna tampil terlebih dahulu (18).Hasil uji organoleptik panelis terhadap tingkat kesukaan pada warna ikan tuna woku dapat dilihat pada Gambar 7.

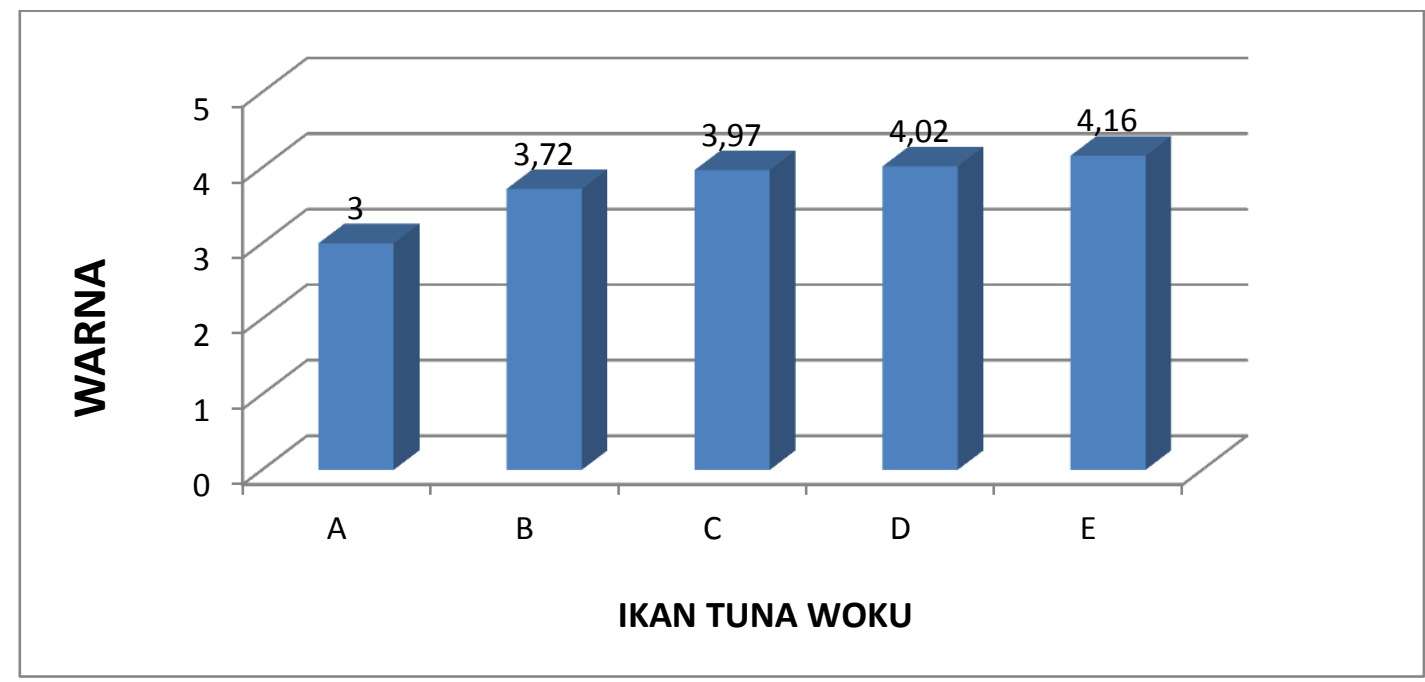

Gambar 7. Uji Organoleptik Ikan Tuna Woku Terhadap Warna

Keterangan :A: Bumbu inti 10\% dan daging ikan 90\%; B: Bumbu inti 15\% dan daging ikan 85\%; C: Bumbu inti $20 \%$ dan daging ikan $80 \%$; D: Bumbu inti $25 \%$ dan daging ikan $75 \%$; E: Bumbu inti $30 \%$ dan daging ikan $70 \%$

Rata-rata penilaian panelis terhadap tingkat kesukaan warna ikan tuna woku berkisar antara 3,00-4,16 (agak suka sampai suka) dari skala hedonik 1-5. Perlakuan yang paling disukai panelis pada tingkat kesukaan warna ikan tuna woku yaitu perlakuan bumbu woku $35 \%$ (E) ratarata penilaian4,16 (suka). Perlakuan penambahan bumbu woku $10 \% \quad$ (A) diperoleh nilai tingkat kesukaan terhadap warna ikan tuna woku rata-rata penilaian 3,00 (agak suka) dengan warna kekuningan. Warna yang menarik dihasilkan dari penambahan bumbu yang lebih banyak. Warna ikan woku yang menarik yaitu warna kuning cerah. Warna kuning ikan woku berasal dari perpaduan bumbu yang ditambahkan terutama kunyit. Kunyit adalah salah satu rempah-rempah yang bisa digunakan dalam masakan Asia. Kunyit kering juga digunakan sebagai bumbu, pemberi warna kuning pada masakan juga sebagai pengawet alami (1).

\section{KESIMPULAN}

Formulasi bumbu inti dengan cita rasa woku dapat diaplikasikan pada ikan tuna. Hasil penelitian yang dapat direkomendasikan yaitu pada perlakuan penambahan bumbu inti rasa woku $30 \%$ (E) diperoleh kadar air 66,96\%, protein $22,30 \%$, lemak $3,73 \%$, kadar abu 2,12\%, angka lempeng total (ALT) $1,5 \times 10^{3} \mathrm{koloni} / \mathrm{g}$, kapang $<10 \mathrm{koloni} / \mathrm{g}$ dengan penampakan 
4,13 (suka), rasa 4,5 (suka), dan warna

4,16 (suka).

\section{DAFTAR PUSTAKA}

[1] Rahmadana, S. Analisa masa simpan rendang ikan tuna dalam kemasan vakum selama penyimpanan pada suhu ruang dan dingin. Program Studi Ilmu dan Teknologi Pertanian. Fakultas Pertanian Universitas Hasanuddin: Makassar;2013.

[2] Melda. Ilmu pangan dasar: Bumbu dan rempah.

http://meldafakhriana.blogspot.co.id/2014/0 1/ilmu-pangan-dasar-bumbu-danrempah.html; 2014. [22 Desember 2016].

[3] Walangitan, AJ. Lumingkewas M.Kumolontang N. Salmon M. Mamesah A, Muis $\mathrm{Y}$. Pembuatan bumbu inti masakan minahasa. Komunikasi No. 203 Balai Penelitian dan Pengembangan Industri: Manado;2000.

[4] SNI 01-2891-1992. Cara uji makanan dan minuman. Dewan Standardisasi Nasional. Jakarta; 1992.

[5] SNI 19-2897-1992. Cara uji cemaran mikroba. Dewan Standardisasi Nasional. Jakarta; 1992.

[6] Suryono M, Harijono, Yunianta. Pemanfaatan ikan tuna (yellowfin), ubi jalar (Ipomoea batatas) dan sagu (Metroxylon sago sp) dalam pembuatan kamaboko. Jurnal Teknologi Pertanian.Vol 14. No 1. Hal 9-10;2013.

[7] Winarno FG. Kimia pangan dan gizi. Jakarta: PT Gramedia;2008.

[8] Nurwati. Formasi hard candy dengan penambahan ekstrak buah papeda (Sonneratia caseolaris) sebagai flavor. Fakultas Perikanan dan IImu Kelautan. IPB. Bogor;2011.

[9] Syah D. Pengantar teknologi Pangan. PT Penerbit IPB Press. Bogor;2012.

[10] Muchtadi RT, Sugiyono. Prinsip proses dan teknologi pangan. Bandung: CV Alfabeta;2014.

[11] Wahyuni R. Optimasi pengolahan kembang gula jelly campuran kulit dan daging buah naga super merah (Hydrocereus constaricensis) dan perkiraan biaya produksi. Universitas Brawijaya;2010.

[12] Sudarmadji S, Haryono B, dan Suhardi. Analisa bahan makanan dan pertanian. Liberty Yogyakarta kerjasama Pusat Antar Universitas Pangan dan Gizi Universitas Gadjah Mada.Yogyakarta;1996.
[13] Fardiaz S. Praktek mikrobiologi pangan. Lembaga Sumber Daya Informatik. IPB. Bogor;1989.

[14] Winarno FG. Kimia pangan dan gizi. Jakarta: Gramedia Pustaka Utama;1991.

[15] Angga. Manfaat serai untukkesehatan. http://harmonibersaudara.com/blog/selainuntuk-masakan-serai-bermanfaat-untukkesehatan;2001. [22 Desember 2016].

[16] Wahyudi. Optimasi formulasi produk ekstruksi snack makaroni dari tepung sukun (Artocapus atlis) dengan metode desain campuran (mixture design). ITB. Bandung;2012.

[17] Sitompul NP. Studi pengolahan dan lama penyimpanan saus cabai dari bahan dasar cabai merah (Capsicum annuum L.) dan cabai rawit (Cappsicum frutences L.) yang difermentasi. Fakultas Pertanian Universitas Hasanuddin. Makassar;2012.

[18] Winarno. Kimia pangan dan gizi. PT Gramedia. Jakarta;2004. 
